\title{
See no Evil
}

\author{
Stacey Baker
}

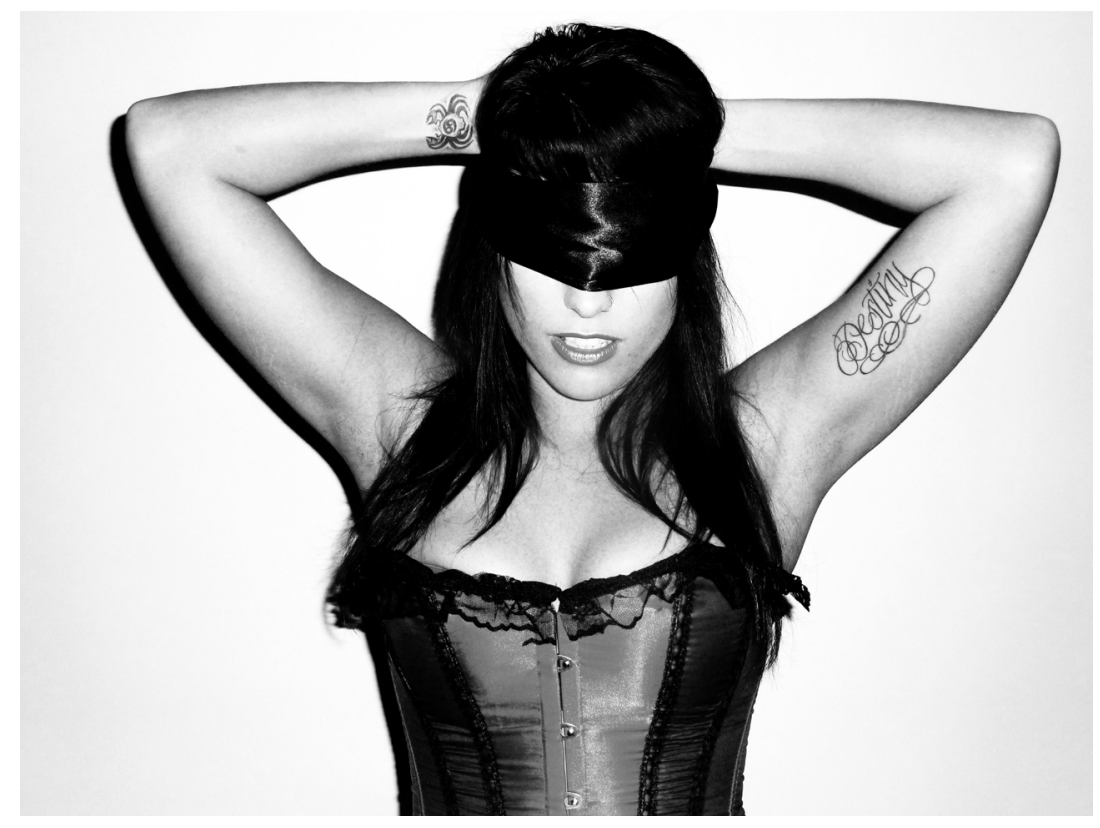

90 | Offset no. 11 